\title{
ELECTRON MICROSCOPICAL OBSERVATIONS ON GAMETOGENESIS AND FERTILIZATION IN CULTURED PLASMODIUM FALCIPARUM
}

\author{
TADASUke ONO ${ }^{1}$, TOSHIO NAKABayashi ${ }^{2}$ AND Yoshiniro OHNishi ${ }^{1}$ \\ Received November 6 1990/Accepted December 141990
}

\begin{abstract}
Electron microscopical studies were performed on gametogenesis and fertilization of the gametes developed in the prolonged culture of $P$. falciparum gametocytes which appeared during the culture of the parasites in the gametocytogenesisinduction medium. When the erythrocyte plasma membrane separated from the gametocyte during gametogenesis, a small part of the gametocyte cytoplasm which was enveloped with the multilayered sheaths of the erythrocyte plasma membrane, was released from the gametocyte into culture medium. We could observe the process of penetration of the macrogamete cytoplasm by the microgamete and then the fusion of the membrane surrounding microgamete with the nuclear envelope of macrogamete. From the findings of two microgamete nuclei were present in the cytoplasm of a macrogamete at fertilization, it is assumed that the multiple nuclear-fusion may occur.
\end{abstract}

\section{INTRODUCTION}

The process of gametogenesis and fertilization of Plasmodium have been examined with electron microscope (Sinden et al., 1976, 1978; Aikawa et al., 1984). Sinden et al. (1976) described the fusion of the plasma membrane of male and female gametes at fertilization in $P$. yoelii. Aikawa et al. (1984) observed in P. gallinaceum that the male nucleus appeared to travel through a channel of the endoplasmic reticulum to a region of the female nucleus. However, these workers did not observe the process of penetration of the macrogamete cytoplasm by the microgamete and the subsequent nuclear fusion of these gametes. Since Ono et al. (1986) introduced the gametocytogenesis induction method for P. falciparum strains which seldom produce gametocytes in the routine culture, it has become easy to study gametocytogenesis in vitro. Ono and Nakabayashi (1989) found that the gametocytes which appeared in the gametocytogenesis-induction medium developed subsequently to the ookinetes in the prolonged culture medium. In the present experiment, ultrastructural observations were carried out on mature gametocytes and the gametes which developed in the

Department of Protozoology, Research Institute for Microbial Diseases, Osaka University, Suita Osaka 565, Japan

1 Present address; Department of Veterinary Epidemiology, College of Agriculture, University of Osaka Prefecture, Mozu-Umemachi, Sakai, Osaka 591, Japan

2 Present address; Department of Parasitology, School of Medicine, Fujita-Gakuen Health University, Kutsukake-Cho, Toyoake 470-11, Japan 
prolonged culture of $P$. falciparum gametocytes. Studies were focussed upon (1) the release of a small part of the gametocytes cytoplasm into culture medium during gametogenesis, (2) the process of penetration of the macrogamete cytoplasm by the microgamete at fertilization, (3) the fusion of the membrane surrounding the microgamete nucleus with the outer membrane of the macrogamete nucleus.

\section{Materials AND Methods}

Species of Plasmodium: Falciparum-Vietnam-Oaknoll (FVO) strain of Plasmodium falciparum was provided by courtesy of Dr. W.A. Siddiqui, Department of Tropical Medicine, University of Hawaii in 1983. This strain has been used in the previous reports (Ono et al. 1986; Ono and Nakabayashi, 1989, 1990). Gametocytes are seldom produced in this culture strain under normal culture conditions. The strain was cultured by the method of Siddiqui (1979) in 100-m $l$ Erlenmeyer flasks, but Falcon tissue culture dishes were used for the prolonged culture of gametocytes which appeared after the gametocytogenesis-induction.

Induction of gametocytogenesis: Gametocytogenesis-induction medium (RPMI-FSC reactive medium) was used for induction of gametocytogenesis. This medium was prepared by the method described in our previous report (Ono and Nakabayashi, 1989). To put it briefly, this medium consists of a mixture of $4 \mathrm{~m} l$ regular RPMI 1640 medium, $4 \mathrm{~m} l$ RPMIFSC medium, and $1 \mathrm{~m} l$ horse serum. RPMI-FSC medium was prepared by dissolving powdered RPMI 1640 medium in the mixture of the culture supernatant of the anti- $P$. falciparum antibody producing hybridoma cells and the hybridoma cell lysate. The hybridoma cells used in the present study were the same cell line as used in the previous report (Ono and Nakabayashi, 1989).

Prolonged culture of gametocytes: The method for the prolonged culture of gametocytes was described previously (Ono and Nakabayashi, 1989). On day 5 of culture in the regular RPMI 1640 medium containing 10\% horse serum, the medium was replaced by a mixture of $9 \mathrm{~m} l$ RPMI-FSC reactive medium containing $10 \%$ horse serum, $0.5 \mathrm{~m} l$ concanavalin A (200 $\mu \mathrm{g} / \mathrm{m} l)$, and $0.2 \mathrm{~m} l$ caffeine $(100 \mathrm{mM} / \mathrm{m} l)$ to induce gametocytogenesis. After culturing for $24 \mathrm{hr}$, the medium was replaced by Waymouth's MB 753/1 medium with para-aminobenzoic acid (final concentration, $1 \mu \mathrm{g} / \mathrm{m} l$ ) containing $10 \%$ horse serum; thereafter the medium was renewed every $24 \mathrm{hr}$. The parasites, which had been maintained in $100-\mathrm{m} l$ Erlenmeyer flasks until the day 3 of culture in Waymouth's medium, were transferred into $60-\mathrm{mm}$ Falcon tissue culture dishes for candle jar culture and cultured for 10 days. The temperature was constantly maintained at $37^{\circ} \mathrm{C}$ through the cultivation. The exflagellating medium (Carter and Beach, 1977) was not used in the present experiment.

Transmission electron microscopic observations: On day 13 of culture in Waymouth's medium, the parasites were collected by centrifugation at $3,000 \mathrm{rpm}$ for $10 \mathrm{~min}$ and the sediment was fixed at $4^{\circ} \mathrm{C}$ for $1 \mathrm{hr}$ in $0.01 \mathrm{M}$ phosphate buffer ( $\mathrm{pH}$ 7.4) containing $2.5 \%$ glutaraldehyde, washed for $1 \mathrm{hr}$ with $0.01 \mathrm{M}$ phosphate buffer $(\mathrm{pH} 7.4$ ) containing $0.25 \mathrm{M}$ sucrose and postfixed at $4^{\circ} \mathrm{C}$ for $1 \mathrm{hr}$ with $1.5 \%$ osmium tetroxide in isotonic buffer. After washing by centrifugation, the pellet was stained with $1 \%$ uranyl acetate solution for $1 \mathrm{hr}$. Then, the samples were dehydrated in absolute ethanol, treated with propylene oxide and embedded in epoxy resin. The sections were double stained with uranyl acetate and lead citrate. 


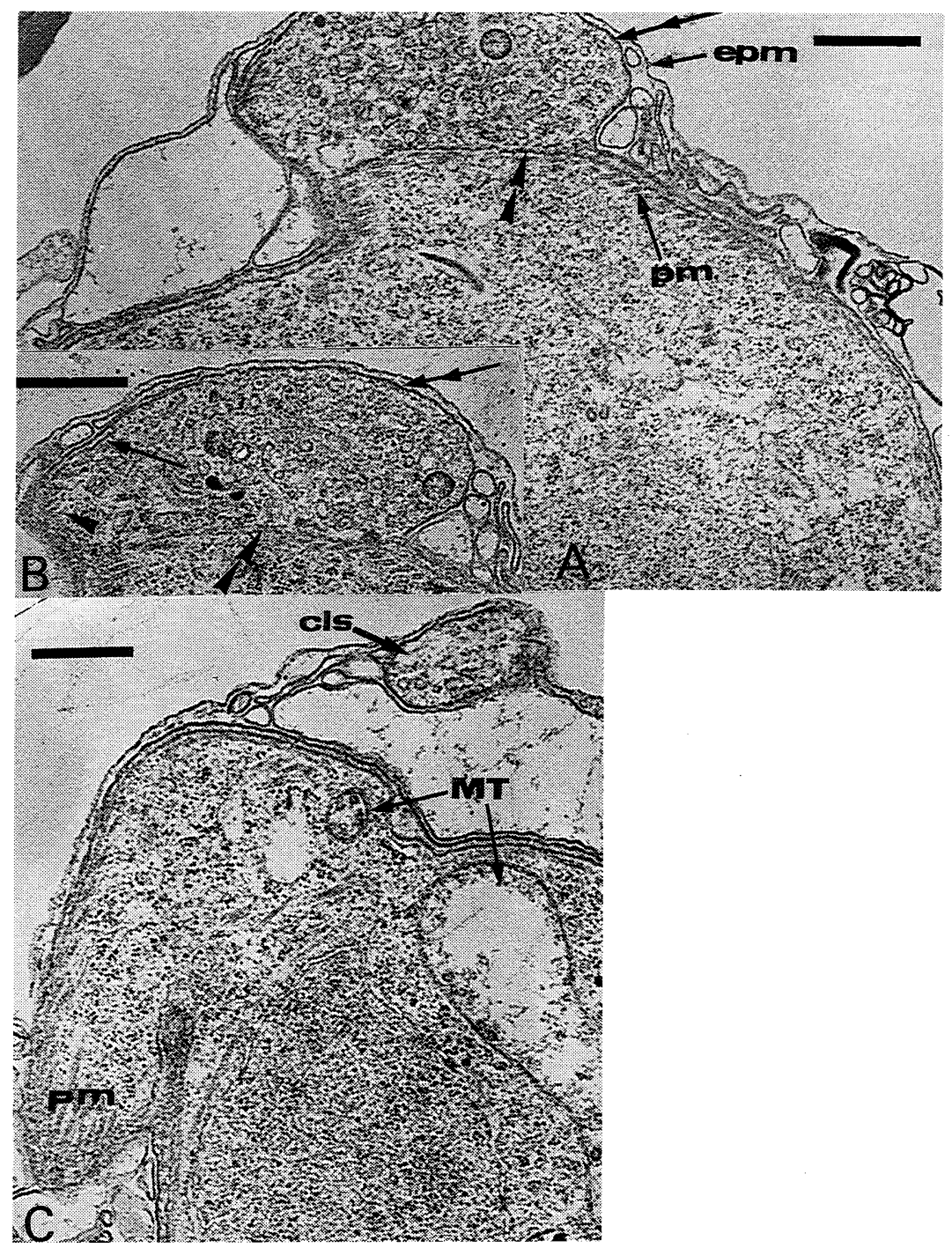

Figure 1A shows same gametocyte during gametogenesis as Fig. 1B but a different section. The extended inner membrane (double arrow heads) of the gametocyte plasma membrane divides the cytoplasm into two parts of a protruding part and a major part. The cytoplasm of protruding part contains ribosomes, a large number of small vesicles. In Fig. 1B, remnant of the inner membrane (arrow) and a few pellicular microtubules (arrow head) are visible clearly beneath the outer membrane (double arrow) in the cytoplasm of a protruding part. epm=erythrocyte plasma membrane; $\mathrm{pm}=$ pellicular microtubules. In gametocyte during gametogenesis shown in Fig. 1C, the cytoplasm-like structure (cls) which is enclosed by the disrupted erythrocyte plasma membrane, contains the similar contents as seen in the protruding part of gametocyte shown in Figs. $1 \mathrm{~A}$ and B. A small mitochondrion and many pellicular microtubules $(\mathrm{pm})$ are present in the cytoplasm of the protruding part. $\mathrm{MT}=$ mitochondrion. Scale bar equals approx. $0.5 \mu \mathrm{m}$ in Figs. 1A, B, C. 


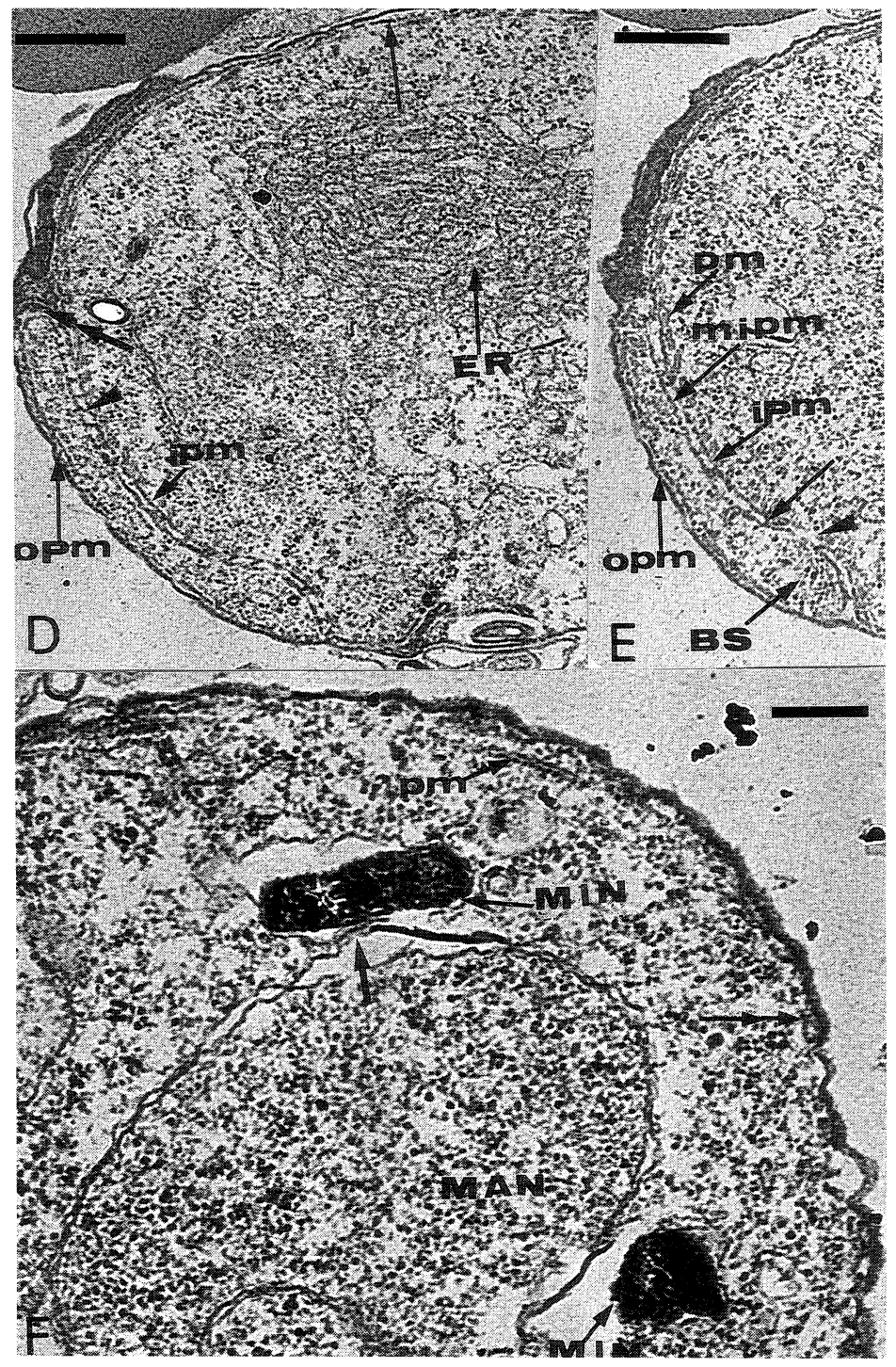

Figure $1 \mathrm{D}$ is the same macrogamete as Fig. $1 \mathrm{E}$ but a different section. A microgamete is seen between the outer (opm) and the inner (ipm) plasma membrane of a macrogamete. Pellicular microtubules $(\mathrm{pm})$, partially disrupted inner membrane (arrow in Fig. 1D), extensive endoplasmic reticulum (ER) and macular desmosomes (arrow head in Fig. 1D) are observed in a macrogamete. The microgamete has a joint structure (double arrow in Fig. 1D). Fusion of a microgamete plasma membrane (mipm) and the inner membrane of macrogamete plasma membrane (ipm) can be seen (arrow in Fig. 1E). In the vicinity of this part, two membranes are indistinct in part (arrow head in Fig. 1E). BS=bulbous swelling. In Fig. 1F, two condensed microgamete nuclei (MIN) are observed near the nucleus of the macrogamete (MAN). The membrane enclosing a cigar-shaped nucleus of the microgamete is fused (arrow in Fig. 1F) with the outer one of two dissociated membrane of the macrogamete nucleus. The disrupted inner membrane of the macrogamete can be seen only in some places (double arrow in Fig. $1 \mathrm{~F}$ ). pm=pellicular microtubules. Scale bar equals approx. $0.5 \mu \mathrm{m}$ in Figs. $1 \mathrm{D}$ and E; $0.25 \mu \mathrm{m}$ in Fig. $1 \mathrm{~F}$. 


\section{RESULT}

Figures $1 \mathrm{~A}$ and $\mathrm{B}$ are the same gametocyte during gametogenesis but in the different sections. In Fig. 1A, a gametocyte is surrounded with the disrupted plasma membrane of an erythrocyte visible as multilayered sheaths. The extended inner membrane of the gametocyte plasma membrane divides the cytoplasm into two parts of a protruding part and a major part. Pellicular microtubules are observed below the inner membrane surrounding the cytoplasm of the major part. In Fig. 1C, a gametocyte during gametogenesis has a protruding part, as in Figs. 1A and B. The cytoplasm-like structure which is enclosed by the disrupted erythrocyte plasma membrane, contains many small vesicles. The contents of the structure are similar to it of the cytoplasm of the protruding part shown in Figs. 1A and B. A large vacuolated mitochondrion which contains a few tubular crista, is present in the cytoplasm of a major part. Figures $1 \mathrm{D}$ and $\mathrm{E}$ are the same macrogamete but in the different sections. A microgamete is seen between the outer and the inner plasma membrane of the macrogamete. The microtubules remain beneath the pellicular membrane. But, the macrogamete is not more enclosed in the erythrocyte plasma membrane and the inner membrane of the macrogamete is disrupted partially. A joint structure is observed in a microgamete. Macular desmosomes are present between the membrane of a microgamete and the inner membrane of macrogamete plasma membrane. Fusion of these two membranes can be seen in the neighborhood of the bulbous swelling of microgamete. In the vicinity of a fused part, two membranes are indistinct in a part. Figure $1 \mathrm{~F}$ shows the fusion of the membrane enclosing the microgamete nucleus with the nuclear membrane of the macrogamete. In Fig. 1F, two condensed microgamete nuclei are observed in the cytoplasm of macrogamete. The macrogamete is surrounded by two layered plasma membranes, the outer membrane and the disrupted inner membrane. The latter can be seen only in some places. But, a small number of the pellicular microtubules still remain beneath the plasma membrane. The erythrocyte plasma membrane is invisible in the neighborhood of the macrogamete.

\section{DISCUSSION}

When the erythrocyte plasma membrane separated from the gametocyte during gametogenesis, a small part of the gametocyte cytoplasm which was enveloped with the multilayered sheaths of the erythrocyte plasma membrane, was released from the gametocyte into culture medium. This phenomenon is unknown until now. We concerned about whether the mature gametocytes developed in the midgut of the mosquitoes which engorged a $P$. falciparum patient release a part of the cytoplasm as those developed in the in vitro culture or not. Penetration of the macrogamete by the microgamete is so rapid that the ultrastructure of the microgamete just after penetration has not been observed until now. In the present study, however, we could observed a microgamete between the outer and the inner plasma membrane of the macrogamete. The microgamete is about to penetrate to the cytoplasm of the macrogamete by fusion of the microgamete plasma membrane and inner membrane of macrogamete plasma membrane. Furthermore, we observed the fusion of the membrane surrounding the microgamete nucleus with the outer membrane of the macrogamete nucleus. A joint structure (double arrow in Fig. 1D) in a microgamete has not been observed until now. This structure is regarded as a convenient structure to detach the nuclear part of 
microgamete which is essential for nuclear fusion.

The multiple fertilization has not been observed in Plasmodium. Nijhout and Carter (1978) found light microscopically in Plasmodium gallinaceum that after the fusion of a microgamete and a macrogamete, entry of other microgametes into the same macrogamete was apparently prevented. But, Aikawa et al. (1984) could not find any evidence for this prevention by electron microscopic observation of a fertilized macrogamete of $P$. gallinaceum. Electron microscopy in the present study revealed two microgamete nuclei surrounded by the membrane in the cytoplasm of a fertilized macrogamete. It is interested in the whether multiple fusion occurs or not.

\section{REFERENCES}

1) Aikawa, M., Carter, R., Ito, Y. and Nijhout, M.M. (1984): New observations on gametogenesis, fertilization and zygote transformation in Plasmodium gallinaceum, J. Protozool., 31, 403-413

2 ) Carter, R. and Beach, R.F. (1977): Gametogenesis in culture by gametocytes of Plasmodium falciparum, Nature, 270, 240-241

3 ) Nijhout M.M. and Carter R. (1978): Gamete development in malaria parasites. Bicarbonatedependent stimulation by $\mathrm{pH}$ in vitro, Parasitology, 76, 39-53

4 ) Ono, T., Nakai, T. and Nakabayashi, T. (1986): Induction of gametocytogenesis in Plasmodium falciparum by the culture supernatant of hybridoma cells producing anti- $P$. falciparum antibody, Biken J., 29, 77-81

5 ) Ono, T. and Nakabayashi, T. (1989): Gametocytogenesis induction in cultured Plasmodium falciparum and further development of the gametocytes to ookinetes in prolonged culture, Parasitol. Res., 75, 189-193

6 ) Ono, T. and Nakabayashi, T. (1990): Gametocytogenesis induction by ammonium compounds in cultured Plasmodium falciparum, Internat. J. Parasitol., 20, 615-618

7 ) Siddiqui, W.A. (1979): Continuous in vitro cultivation of Plasmodium falciparum in human erythrocytes: Description of a single technique to obtain high yields of parasites. In: Pract. Tissue Culture Applic. (Edited by Marmorch, K. and Hirumi, H.), pp. 267-277 Academic Press Inc.

8 ) Sinden, R.E., Canning, E.U. and Spain, B. (1976): Gametogenesis and fertilization in Plasmodium yoelii nigeriensis: a transmission electron microscope study, Proc. Roy. Soc. London B, 193, 55-76

9 ) Sinden, R.E., Canning, E.U., Bray, R.S. and Smalley, M.E. (1978): Gametocyte and gamete development in Plasmodium falciparum, Proc. Roy. Soc. London B, 201, 375-399 
培養熱帯熱マラリア原虫における生殖体形成 および受精に対する電子顕微鏡的観察

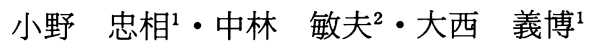

熱帯熱マラリア原虫赤内型の in vitro 培養に際し, これに抗熱帯熱マラリア原虫抗体産生ハイ ブリドーマ細胞の上清液を加えて誘発した生殖母体を長期培養すると, 生殖体形成, 受精, 融合 体形成, 虫様体形成と発育が進む。この論文では生殖体形成中の生殖母体, 雄性生殖母体による 雌性生殖体侵入, 更に雌雄生殖体による受精を, 電子顕微鏡によって観察した。その結果, 次の 所見が得られた。

1. 生殖母体の 2 枚の細胞質膜の中, 内膜が伸展して生殖母体の細胞質の一部が分割される。そ して, この部分は生殖母体を包んでいた赤血球膜が生殖母体から剥れる時, 赤血球膜に包ま れて虫体から培地中に放出された。

2. 雄性生殖体は雌性生殖体侵入に際して, まず雌性生殖体細胞質外膜下に入り, その後雄性生 殖体膜と雌性生殖体細胞質内膜の融合によって, 細胞質に入るように思われた。両膜の間に macular desmosome が見られた。雄性生殖体は, 雌性生殖体に入ると核部分がはずれるが, それを容易にすると思われる構造が見られた。

3. 雄性生殖体の核を包む膜と, 雌性生殖体の核膜の融合, すなわち受精を形態的に初めて観察 することが出来た。雌性生殖体細胞質に核が 2 つ認められ, 多受精の可能性が示唆された。

大阪大学微生物病研究所原虫学部門

1 現所属 ; 大阪府立大学農学部獣医疫学講座 (大阪府堺市百舌鳥梅町)

2 現所属; 藤田学園保健衛生大学医学部寄生虫学講座（愛知県豊明市沓掛町） 